\title{
Elina Paukkunen
}

\section{AFRIKKALAISTA TANSSIA OPPIMASSA}

\section{Etnografinen kenttätyö tutkijan oppimisprosessina}

Olen pohtinut senegalilaista sabar-perinnettä käsittelevän tutkimukseni yhteydessä paljon kenttätyön merkitystä vieraan tanssi- ja musiikkikulttuurin tutkimuksessa. Kenttätyö on usein ymmärretty ennen kaikkea materiaalin keräämiseksi. Antropologisessa tutkimusperinteessä korostetaan lisäksi niin sanottua osallistuvaa havainnointia, joka on kuitenkin monesti ymmärretty vain havaintojen kirjaamisena muistiin erilaisissa tilanteissa, jolloin se ei eroa paljonkaan muusta materiaalin keräämisestä. Sen sijaan tutkijan omia kokemuksia ja niiden kautta kertynyttä kulttuurista ymmärrystä on hyödynnetty varsin vähän tutkimuksessa, vaikka tanssin- ja musiikintutkimuksessa osallistuva havainnointi sisältää tavallisesti myös tutkimuksen kohteena olevan tanssin tai musiikin opiskelua. Mielestäni juuri tutkijan oppimisprosessi on kuitenkin keskeisin osa kenttätyötä, ja kerätty materiaali lähinnä tukee tätä prosessia.

Vieras kulttuuri tai "kenttä" on tyypillisesti nähty alueena, joka on Toinen suhteessa (länsimaiseen) tutkijaan tai jolla tutkija on aina ulkopuolinen (ks. esim. Gore 1999: 211). Käytännössä tutkimuskohteena oleva kulttuuri on monille tutkijoille jo ennen tutkimuksen alkamista tuttu tanssi- tai musiikkiharrastuksen kautta. Vieraaseen kulttuuriin perehtyminen on siten voinut alkaa tutkijan kotimaassa ennen tutkimusprosessin alkua, eikä se rajoitu myöhemminkään vain yhteen paikkaan. Tällöin kenttää ei voida määritellä maantieteellisesti, eikä kenttätyötä pysty selkeästi rajaamaan tiettyyn ajanjaksoon. Tutkimuksen johdosta vieraasta kulttuurista tulee usein myös merkittävä osa tutkijan identiteettiä: erilaisten opettaja-oppilas -suhteiden sekä muiden ihmissuhteiden kautta tutkijasta tulee osa tutkimuskohteena olevan kulttuurin sosiaalisia verkostoja. Lisäksi tutkija joutuu yleensä jollain tavalla toimimaan tutkimansa kulttuurin edustajana tai välittäjänä kotimaassaan. Näin tutkija tulee osaksi omaa kenttäänsä, eikä kenttätyökään voi olla neutraalia tiedon "keräämistä" tai tapahtumien dokumentointia vaan ennemminkin sosiaalista toimintaa, jonka puitteissa tutkijan on mahdollista laajentaa ymmärrystään tutkimuskohteestaan.

Tutkimukseni senegalilaisen tanssin ja musiikin vuorovaikutuksesta yhtenä lähtökohtana on nimenomaan tanssiharrastuksen parissa syntynyt kiinnostus siihen, miten länsiafrikkalaiset tanssijat ja muusikot kommunikoivat liikkeiden ja rytmien avulla esitystilanteissa. Kysymys saattaa vaikuttaa varsin tekniseltä ja helposti analysoitavalta, mutta jo pelkkä tanssiliikkeiden kuvailu tai musiikkinotaatioiden tekeminen 
on vaikeaa ilman omaa kokemusta siitä, miten liikkeet tai äänet käytännössä saadaan aikaan. Afrikkalaisen tanssin ja musiikin kohdalla ainoastaan filmimateriaaliin perustuvat analyysit ovatkin johtaneet virhepäätelmiin. Lisäksi tanssin ja musiikin tutkiminen edellyttää niiden kulttuuriseen kontekstiin tutustumista. Vaikka lähdekirjallisuutta näistä aiheista olisikin saatavilla, on omakohtainen kokemus tarpeen, jotta tutkija pystyisi arvioimaan lähteiden luotettavuutta ja ennen kaikkea ymmärtämään tutkimiaan ilmiöitä.

Omaan kulttuuriin kohdistuvassa tutkimuksessa tutkijan kokemukseen pohjautuvaa ymmärrystä niin esityskäytännöistä kuin tanssin ja musiikin kulttuurisista merkityksistä pidetään itsestään selvänä, kun taas vierasta kulttuuria käsiteltäessä tutkijan odotetaan esittävän vastaavat tiedot esimerkiksi haastattelusitaatteina tai jollain muulla tavoin dokumentteihin viittaamalla. Tieto voi kuitenkin myös tällaisessa tutkimuksessa pohjautua käytännön harjoittelusta nousevaan oivallukseen esimerkiksi siitä, miten tanssityylin tyypilliset liikkeet toteutetaan ja miten tanssijat ne kyseisessä kulttuurissa hahmottavat. Videotallenteen perusteella voidaan kyllä havainnollistaa sitä, miltä liikkeet näyttävät, mutta ilman omaa tanssikokemusta ei tutkijalla yleensä voi olla käsitystä siitä, miten tanssija itse hahmottaa liikkeensä, sillä tanssiliikkeitä analysoidaan sanallisesti vain harvoissa kulttuureissa.

Tässä artikkelissa pohdin etnografista kenttätyötä tarkastelemalla kenttätyötä vieraan kulttuurin oppimisprosessina, jossa keskeisenä työvälineenä on vuorovaikutus kentän eri toimijoiden välillä. Havainnollistan tätä pohdintaa kokemuksillani länsiafrikkalaisen tanssin ja musiikin opetuksesta ja oppimisesta niin Suomessa kuin Senegalissa. Keskityn lähinnä tanssiin, mutta väistämättä joudun käsittelemään jonkin verran myös musiikkia, sillä länsiafrikkalaisissa kulttuureissa tanssi ja musiikki muodostavat yleensä erottamattoman kokonaisuuden (johon saattaa lisäksi kuulua muitakin taiteenlajeja, ks. esim. Gore 1994: 59-60). Ennen kaikkea haluan kyseenalaistaa perinteisen materiaalin keräämiseen keskittyvän kenttätyökäsityksen sekä vastakkainasettelut, joita tehdään erityisesti dokumenttien ja kokemusten sekä sanallisen ja ei-sanallisen kommunikaation välillä.

\section{Etnografinen kenttätyö}

Etnografisen tanssin- ja musiikintutkimuksen lähtökohdat ovat antropologisessa tutkimusperinteessä, ja siinä korostuu eri taidemuotojen kulttuurisidonnaisuus (esim. Youngerman 1975: 116-117; Kaeppler 1999: 16). Nykyisin ollaan yleisesti sitä mieltä, ettei taiteita edes ole mahdollista tutkia muusta kulttuurista irrallaan, sillä ne ovat läpeensä kulttuurisia ja sosiaalisia ilmiöitä (tanssista esim. Hoppu 2003: 19-20). Siten tanssietnografia voidaan määritellä yksinkertaisesti sen kuvaamiseksi, millaisilla tavoilla ja miksi ihmiset tanssivat, näkökulmasta ja tutkimusperinteestä riippumatta 
(Seeger 1992: 88-89 musiikkietnografiasta). Näin myös tanssin rakenneanalyysi on tärkeä osa etnografista tanssintutkimusta. Useimmiten tällaisen etnografisen kuvauksen tuottaminen edellyttää työskentelyä tarkastelun kohteena olevan kulttuurin parissa eli kenttätyötä.

Kenttä on perinteisesti ymmärretty joko jonain maantieteellisenä paikkana tai jonkin etnisen tai kielellisen ryhmän muodostamana yhteisönä (esim. Myers 1992: 23). Tutkimuskohde voi toki olla rajattu tällaisten kriteerien mukaan, mutta jos kenttätyötä ajatellaan tiedon hankkimisen prosessina, tuntuu määritelmä nykymaailmassa kovin ahtaalta. Kenttä voidaankin ajatella esimerkiksi käsitteellisenä paikkana (Gore 1999: 210), jossa tiedon hankkiminen tapahtuu. Avainasemassa kentän määrittelyssä ovat "informantit" eli henkilöt, joilta tietoa saadaan (esim. Myers 1992: 23)1. Nämä ihmiset eivät aina ole pelkästään tutkimuksen kohteena olevan kulttuurin edustajia (vaikka näin helposti oletetaan), vaan tietoa saadaan myös muilta henkilöiltä. Kenttätyö ei myöskään rajoitu pelkästään sanalliseen kommunikointiin, vaan keskustelujen, haastatteluiden ja kirjallisten lähteiden lisäksi tietoa saadaan havaintojen, kokemusten ja monenlaisen ei-sanallisen viestinnän kautta. Näiden erilaisista tiedonlähteistä kerääntyvän kokonaiskuvan pohjalta myös arvioidaan eri lähteistä saadun tiedon luotettavuutta.

Kenttätyössä materiaalin keräämistä tärkeämpää on mielestäni sosiaalinen kanssakäyminen, sillä vain sen kautta on mahdollista oppia tuntemaan tutkimuksen kohteena olevaa kulttuuria eli ihmisten ajattelu- ja toimintatapoja (ks. myös Kaeppler 1999: 17). Ilman tätä ymmärrystä ei esimerkiksi haastattelujen ja esitystaltiointien tulkitseminen ole mielekästä. Tästä syystä näen erilaiset dokumentit, kuten muistiinpanot, videotallenteet, äänitteet ja valokuvat ennemminkin jonkinlaisina muistiapuina, joiden avulla dokumentoidut tilanteet on helpompi palauttaa mieleen ja joiden avulla niitä on mahdollista analysoida tarkemmin kuin pelkän muistin varassa. Näitä olennaisempia ovat kuitenkin tutkijan omat kokemukset ja niiden kautta kertynyt ymmärrys tutkimuskohteesta. Siten kentän käsite sisältää myös tutkijan itsensä (ks. myös Hastrup 1995: 51). Samaan tapaan Michelle Kisliuk (1997: 32) on kuvannut kenttää sosiaaliseksi maisemaksi tai ihmissuhteiden verkostoksi, jossa tutkijan on löydettävä oma paikkansa eli rakennettava identiteettiään tutkijana, sillä toisia ihmisiä - ja heidän kulttuuriaan - voi oppia tuntemaan vain tekemällä itsensä tutuksi heille. Näin ollen tutkija ei pysty vapaasti määrittelemään kenttäänsä, sillä ihmiset vaikuttavat toisiinsa tavoilla, joita ei voi kontrolloida. (Kisliuk 1997: 24-27, 43; ks. myös Gore 1999: 217.)

On tietenkin helpompi antaa ohjeita siitä, miten videonauhuria käytetään tai miten haastattelutilanteisiin kannattaa valmistautua, kuin siitä, millä tavalla vierasta kulttuuria tulisi lähestyä tai miten omia kokemuksia voi hyödyntää tutkimuksessa.

1 Pidän termiä 'informantti' kyseenalaisena, sillä se tuntuu objektivoivan ihmiset persoonattomiksi tietolähteiksi (ks. myös Hastrup 1995, 25). Pyrinkin jatkossa puhumaan tanssijoista, tanssinopettajista, muusikoista tms. 
Yleisluontoisia ohjeita voi olla mahdoton antaa, sillä kaikki kulttuurit ovat erilaisia, samoin kuin ihmiset yksilöinä (esim. Kubik 2000: 8). Aloittelevaa tutkijaa saatetaan kyllä varoitella esimerkiksi kulttuurishokista ja lohdutella sen menevän vähitellen ohi (esim. Myers 1992: 33-35). Tuntuisi kuitenkin rakentavammalta esittää tämä vieraan elämäntavan keskelle joutumisen aiheuttama järkytys yhtenä vaiheena prosessissa, joka voi johtaa toisenlaisten ajattelu- ja toimintatapojen ymmärtämiseen. Tuntuu myös varsin oudolta, että tutkijat itse niin usein ohittavat kenttätyökokemuksensa maininnalla siitä, kuinka kauan he oleskelivat kentällä - tarkoittaen tällöin tietenkin tiettyä maantieteellistä paikkaa. Oleskelu tutkittavan kulttuurin keskellä on tietenkin tärkeää, mutta jos kenttätyöksi hyväksytään vain ajallisesti tarkkaan rajattu, tehokas ja päämäärätietoinen tutkimusjakso, suljetaan suuri määrä tietämystä tutkimuksen ulkopuolelle (Agawu 2003: 41-46).

Itse olin harrastanut länsiafrikkalaisia tansseja noin kymmenen vuotta ennen nykyisen tutkimukseni aloittamista, enkä siten pysty ajattelemaan, että olisin aloittanut kenttätyöni vasta muutama vuosi sitten Senegalissa. Aluksi nämä tanssitunnit olivat minulle lähinnä mukava liikuntaharrastus, mutta kun kiinnostuin - osittain juuri tanssituntien välityksellä - myös länsiafrikkalaisesta musiikista, aloin vähitellen hakea lisätietoa ensin muusikoista ja sitten heidän kotimaidensa musiikista ja kulttuurista laajemminkin. Samoin musiikkitieteen opinnoissanikin aloin perehtyä enemmän afrikkalaiseen musiikkiin, ja lopulta päätin myös ottaa Afrikan-tutkimuksen sivuaineekseni. Samoihin aikoihin aloin opetella djembe- ja sabar-rumpujen soittamista. Halusin siis jo paljon ennen nykyisen tutkimukseni aloittamista ymmärtää länsiafrikkalaisia musiikkityylejä ja tansseja sekä niiden kulttuurisia konteksteja, ja pyrin kehittämään tätä ymmärrystä niin harrastuksessani kuin opinnoissani.

Oppimisprosessi tutkimusaiheeni parissa alkoi suomalaisten tanssinopettajien johdolla, ja heiltä saadut tiedot ja taidot ovat olleet tärkeitä lähtökohtia tanssin havainnoimisessa ja opiskelemisessa myöhemmin Senegalissa. Hyödyllistä tietoa olen saanut myös monilta Senegalissa asuneilta suomalaisilta sekä tietenkin kirjallisuudesta. Tästä huolimatta kokonaiskuva tutkimastani wolofien ${ }^{2}$ tanssi- ja musiikkikulttuurista alkoi selkiytyä minulle vasta kun ensimmäisen kerran oleskelin Senegalissa vuonna 2000. Tuolloin keräsin materiaalia populaarimusiikkia käsittelevään graduuni, mutta seurasin ja opiskelin myös perinteistä musiikkia ja tanssia. Vaikka ymmärtämisen kannalta olikin siis olennaista päästä paikan päälle, haluan tässä korostaa Suomessa tapahtuneiden opintojen merkitystä: ilman niiden muodostamaa pohjaa en todennäköisesti olisi pystynyt saamaan yhtä paljon irti tuosta ensimmäisestä, kolme kuukautta kestäneestä matkastani. Sittemmin olen käynyt Senegalissa neljä kertaa. Kolme matkoista oli lyhyitä, noin kuukauden mittaisia, ja niiden aikana olen lähinnä ottanut soitto- ja

2 Wolofit ovat Senegalin suurin etninen ryhmä, ja wolof on jonkinlainen lingua franca Senegalissa, vaikka maan virallinen kieli onkin ranska. 
tanssitunteja sekä seurannut Dakarin musiikkielämää. Neljäs matka oli pitempi, joulukuusta 2005 heinäkuuhun 2006, ja sen aikana keräsin suurimman osan tekeillä olevan väitöskirjani materiaalista. Lisäksi olen jatkanut tanssi- ja soitto-opintoja kotona Suomessa niin suomalaisten kuin afrikkalaisten opettajien johdolla.

Monenlaiset yhteydet niin senegalilaisiin muusikoihin ja tanssijoihin eri puolilla maailmaa, kuten myös Senegalissa asuviin tai asuneisiin suomalaisiin, ovat jatkuneet ensimmäisestä Senegalin matkastani aina tähän päivään asti ja vaikuttaneet tutkimukseni etenemiseen. Jotkut kontaktit ovat toki katkenneet, mutta toiset ovat puolestaan synnyttäneet uusia. Paljon ajattelemisen aihetta ovat antaneet erityisesti senegalilaisten opettajien vierailut Suomessa. Koska olen ollut joidenkin heistä yksityisoppilaana Dakarissa, minulla on ollut mahdollisuus tarkastella heidän opettamistyyliään erilaisissa tilanteissa ja ympäristöissä - kotimaassaan yhden oppilaan kanssa ja Suomessa suuren ryhmän edessä - sekä verrata heidän opetustaan suomalaisiin opettajiin. Nämä erilaiset opettamistyylit ovat tarjonneet hyödyllisiä näkökulmia opeteltavaan tanssiin ja musiikkiin, esimerkiksi opettajien vaikeudet omaksua suomalaisille oppilaille ryhmäopetukseen sopiva tapa opettaa tanssia ovat paljastaneet olennaisia asioita heidän tavoistaan hahmottaa niin tanssia kuin musiikkia. Ylipäätäänkin kommunikaatiovaikeudet senegalilaisten opettajien kanssa ovat joskus osoittautuneet arvokkaiksi kokemuksiksi jälkikäteen ajatellen.

Olen tässä hahmotellut lyhyesti oppimisprosessini vaiheita ja siihen vaikuttaneita henkilöitä, oppimisen sisältöjä käsittelen tanssin osalta seuraavassa luvussa. Kuten edellä kertomastani voi huomata, oli nykyinen tutkimusaiheeni, senegalilainen tanssi ja musiikki, monin tavoin osa elämääni jo ennen kun aloin muotoilla tutkimukseni tavoitteita tarkemmin vuonna 2002, ja sitäkin enemmän vuoteen 2005 mennessä, josta lähtien olen pystynyt keskittymään tutkimukseeni täysipainoisemmin. Olennaista lienee huomauttaa, että edellä mainitsemistani yhteyksistä niin senegalilaisiin kuin muunmaalaisiin "informantteihini" vain äärimmäisen harvat ovat olleet puhtaasti ammatillisia, siis vain tutkimuksen takia muodostuneita ja ylläpidettyjä - suurinta osaa näistä ihmisistä voin kutsua ystäviksi tai tuttaviksi. Lisäksi koen oppineeni monia asioita senegalilaisesta tanssista ja musiikista opettaessani tutkimiani tansseja muille, eli olen välillä myös itse toiminut omana tietolähteenäni. Jokainen henkilö tässä kenttäni ihmissuhdeverkostossa on tarjonnut (ja tarjoaa) omanlaisensa näkökulman tutkimuskohteeseeni ja siten vaikuttanut tavalla tai toisella oman näkemykseni muotoutumiseen. Haluan tässä painottaa sitä, ettei keneltäkään saatua tietoa voi pitää itsestäänselvästi muita parempana esimerkiksi henkilön kotimaan perusteella, sillä jopa väärinkäsityksiin perustuvat mielipiteet voivat avata jonkin hedelmällisen näkökulman tutkimusaiheeseen. 


\section{Tanssin opiskelua Suomessa ja Senegalissa}

Suomessa kasvaneena oma länsiafrikkalaisten tanssien oppimisprosessini on lähtökohtaisesti toisenlainen kuin Senegalissa kasvaneiden tanssinopettajieni, jotka ovat lapsesta asti päässeet seuraamaan erilaisia tanssitilanteita ja osallistumaan niihin. Koska uuden tanssi- ja musiikkityylin omaksuminen on pitkä prosessi, olisi tutkimukseni tekeminen todennäköisesti mahdotonta ilman harrastustaustaani. Vaikka tanssia ja musiikkia on periaatteessa mahdollista kuvailla ja analysoida ilman käytännön tanssitai soittokokemusta, on tarkoitukseni myös selvittää wolofien kulttuurille ominaista tapaa hahmottaa sabar-tansseja ja niihin liittyvää musiikkia. Itse pidän tämän hahmotustavan ymmärtämistä kulttuurisensitiivisen analyysin edellytyksenä. Se puolestaan tuskin olisi mahdollista ilman omaa kokemusta tanssimisesta, sillä länsiafrikkalaisissa kulttuureissa tanssia ja musiikkia tai varsinkaan omia tanssikokemuksia ei juurikaan ole totuttu kuvailemaan sanallisesti. En tietenkään tarkoita, että oma kokemukseni sabar-tansseista olisi sama kuin wolof-kulttuurin keskellä kasvaneiden tanssijoiden, vaan ennemminkin sitä, että tanssiopintoni ovat mahdollistaneet monitasoisemman kommunikaation erityisesti senegalilaisten tanssinopettajieni kanssa mutta myös muiden tanssijoiden ja muusikoiden kanssa.

Seuraavassa poimin tarkastelun kohteeksi joitain sabar-tansseille ja wolofien tanssikulttuurille tyypillisiä piirteitä, joihin olen alkanut kiinnittää huomiota nimenomaan tanssiopintojeni yhteydessä. Pyrin jaottelemaan nämä piirteet Suzanne Youngermanin (1975: 117) esittämän mallin mukaisesti tanssin rakenteeseen, tyyliin, kontekstiin ja merkityksiin, joilla Youngerman tarkoittaa kaikenlaisia tanssia koskevia käsityksiä ja tuntemuksia. Nämä teoreettiset tanssin neljä tasoa eivät käytännössä koskaan ole selkeästi erotettavissa toisistaan, ja siten omat esimerkkinikin olisi mahdollista jaotella usein eri tavoin. Tanssin merkitykset jätän pitkälti käsittelemättä, sillä ne ovat kontekstisidonnaisia ja niiden käsittely vaatisi wolofien kulttuurin laajempaa esittelyä. Koska tarkoitukseni tässä ei ole käsitellä tutkimuskohdettani vaan havainnollistaa käytännön tanssiopintojen ja ei-sanallisen kommunikaation roolia tutkimusprosessissani, merkitysten käsittely ei muutenkaan olisi mielekästä.

Länsiafrikkalaisia tansseja ajatellen kaikista mainituista tanssin tasoista voi saada jossain määrin tietoa myös Suomesta käsin, mutta helpoiten täällä pystyy oppimaan jotain tanssien ja musiikin rakenteista. Erityisesti tältä osin on omassa oppimisprosessissani ollut apua suomalaisista tanssinopettajista, jotka ovat osanneet sanallisesti selittää jotain siitä, miten länsiafrikkalaisia tansseja pitäisi tanssia. Koska länsiafrikkalaisissa kulttuureissa tanssin oppiminen perustuu lähinnä muiden tanssijoiden jäljittelyyn, on ymmärrettävää, ettei tanssiliikkeitä myöskään ole tapana selittää sanallisesti. Silloin kun on kyse vieraasta tanssilajista, ei pelkkä liikkeen näyttäminen kuitenkaan aina riitä, vaan on tarpeen selittää, miten tietty liike tehdään tai miltä sen tekemisen pitäisi tuntua. Tähän taas länsiafrikkalaiset opettajat eivät ole tottuneet, ja jos he yrittävätkin 
selittää liikkeitä sanallisesti, selitykset eivät välttämättä ole suomalaisille oppilaille ymmärrettäviä. Tästä syystä uskon, että vieraan tanssilajin opiskelun alkuvaiheissa on yleensä hedelmällisempää, jos opettaja on suomalainen.

Muutkin Suomessa vierailleiden länsiafrikkalaisten opettajien ongelmat kertovat heidän edustamastaan kulttuurista ja sen tavasta hahmottaa tanssia. Lähes kaikille tuntemilleni länsiafrikkalaisille tanssijoille tuottaa liikkeiden sanallisen selittämisen lisäksi vaikeuksia liikkeiden "paloittelu" osatekijöihinsä. Koska he itse ovat oppineet liikkeet yhtenä kokonaisuutena, on heidän hankala ajatella esimerkiksi käsien liikkeitä erillään jalkojen liikkeistä. Myös liikkeiden hidastaminen on heille vaikeaa: usein tanssijat lisäävät hidastaessaan väliaskelia tai muuta ylimääräistä. Liikkeiden hidastaminen on vaikeaa siksi, että tietyt tanssit ja niihin liittyvä musiikki esitetään aina suurin piirtein samassa tempossa. Tempon muuttaminen ei välttämättä tuota muusikoille vaikeuksia, mutta musiikista katoaa temponmuutoksissa helposti sille ominainen luonne. Vastaavasti tanssiliikkeitä on vaikea toteuttaa samalla intensiteetillä eri tempoissa. Jos tempo esimerkiksi hidastuu huomattavasti, alun perin voimakkaasti aksentoidut liikkeet, kuten sabar-tansseille tyypilliset äkilliset suunnanmuutokset, muuttuvat väkisin hillitymmiksi. Liikkeiden keskinäisiä suhteitakin voi olla vaikea pitää samana, sillä esimerkiksi hyppyjen kestoa on mahdotonta pidentää rajattomasti.

Samoin kuin eri liikkeiden kuuluu olla tietyssä suhteessa toisiinsa, myös tanssi ja musiikki määrittelevät toisiaan. Tästä johtuen liike saattaa hahmottua ilman musiikkia aivan eri tavalla kuin musiikin kanssa. Siksi liikkeiden näyttäminen ilman musiikkia on monille tanssijoille vaikeaa, joskus silloinkin kun he laulavat itse rytmiä samalla (kuten useimmat tanssijat tekevät, jos muuta säestystä ei ole). Myös itselleni tuottaa nykyisin ongelmia oppia uusia liikkeitä, jos opettaja näyttää ne ensin ilman musiikkia tai paloittelee ne osatekijöihinsä, ennen kuin olen ehtinyt saada käsityksen kokonaisuudesta. Sen sijaan tanssiopintojeni alkuvaiheessa kokonaisuuden hahmottaminen ei useinkaan onnistunut ennen kuin pystyin tunnistamaan osatekijät, joista se muodostuu, ja tämä näyttää olevan tavallista muillekin suomalaisille tanssinharrastajille.

Jos tanssien rakenteiden opiskelu onkin tiettyyn pisteeseen asti helpompaa Suomesta käsin, on tyylillisten piirteiden hahmottaminen hankalaa ellei ole nähnyt tansseja paikan päällä, monien eri ihmisten tanssimina. Monet länsiafrikkalaiset tanssit sallivat varsin paljon yksilöllistä variaatiota liikkeiden toteuttamisessa, ja naisten ja miesten tanssityylit eroavat toisistaan, vaikka liikkeet voivat olla samoja. Usein esimerkiksi liikkeiden laajuudella tai niiden tarkalla suunnalla ei ole kovin suurta merkitystä, vaan tärkeämpää on liikkeiden rytminen tarkkuus ja oikeanlainen aksentointi. Sabar-tansseissa erityisesti käsien liikkeissä on runsaasti liikkumavaraa: usein tanssija pitää toisella kädellään kiinni vaatteistaan ja toinen tasapainottaa jalkojen liikkeitä, mutta monimutkaisemmatkin liikesarjat ovat mahdollisia. Periaatteessa sama liikefraasi voi siten näyttää varsin erilaiselta eri tanssijoiden esittämänä, varsinkin kun jalkojen liikkeet eivät välttämättä erotu selvästi vaatteiden alta. Siksi ei olekaan ihme, 
että ensimmäiset Senegalissa näkemäni sabar-tanssit näyttivät minusta lähinnä kaoottiselta huitomiselta, mutta pian aloin kyllä tunnistaa niistä tanssitunneilla oppimiani rakenteita, liikkeitä ja liikesarjoja.

Kuulemani mukaan useille muillekin afrikkalaisen tanssin harrastajille on vasta Afrikassa oleskelun myötä hahmottunut, mikä on joissain liikkeissä olennaista ja mikä taas tanssijan omaa tyyliä - Suomessahan tietty tanssi opitaan ensisijaisesti yhdeltä, tai pidemmän ajan kuluessa ehkä muutamalta opettajalta. Siten tietyn opettajan yksilöllisestä tyylistä muodostuu helposti esteettinen ihanne (ks. Foster 1997: 237), kun oppilas pyrkii jäljittelemään opettajaa niissäkin asioissa, joissa olisi mahdollisuus ottaa vapauksia. Tässä on valtava ero siihen, että Senegalissa ihmiset näkevät jo lapsesta lähtien monenlaisia tanssityylejä erilaisissa esitystilanteissa. Näin yksittäisen henkilön esteettiset käsitykset hyvän tanssijan ominaisuuksista muotoutuvat monenlaisten esikuvien pohjalta ja suhteessa yhteisössä vallitseviin esteettisiin arvoihin.

Tanssin konteksteista Senegalissa voi tietenkin lukea esimerkiksi kirjallisuudesta, mutta niiden ymmärtäminen voi silti olla vaikeaa, jos itse ole päässyt niitä havainnoimaan, sillä kontekstit kytkeytyvät vahvasti merkityksiin. Luen tässä konteksteihin myös esitys- ja opetuskäytännöt, joiden tarkastelu on ollut tärkeässä roolissa omassa oppimisprosessissani. Suomalaisessa tanssisalissa sabar-tanssit näyttäytyvät helposti toisenlaisina kuin alkuperäisessä ympäristössään senegalilaisissa juhlissa, jossa niitä esitetään lyhyinä improvisoituina sooloina. Suomessa afrikkalaisen tanssin tunneilla opetus tapahtuu kuitenkin ryhmässä, joten opetettavat tanssit ovat enimmäkseen pitempiä, perinteisten soolojen liikemateriaalia hyödyntäviä koreografioita.

Usein nämä suomalaisten afrikkalaisen tanssin tuntien koreografiat ovat joko kokonaan tai osittain peräisin ammattimaisten tanssi- ja musiikkiryhmien repertuaareista. Nämä ryhmät sovittavat oman maansa perinteisiä tansseja näyttämölle ja tietenkin myös harjoittelevat koreografioitaan. Niin Senegalissa kuin Suomessa näkemäni afrikkalaisen tanssin ja musiikin näyttämöesitykset ovat noudattaneet pitkälti länsimaisen taidetanssin esityskäytäntöjä. Oletettavasti tällaisten ryhmien esityksissä tanssijoille ei myöskään sallita yhtä paljon tyylillisiä vapauksia kuin tanssin perinteisissä konteksteissa, sillä ryhmäkoreografioissa on tärkeää liikekielen yhtenäisyys. Esityksiin on kyllä sisältynyt myös joitain sooloja, mutta osasta on vaikea sanoa, ovatko ne olleet improvisoituja vai ennalta harjoiteltuja. Improvisaatiolle on ollut tilaa ainakin silloin, kun yleisölle on annettu mahdollisuus osallistua tanssimiseen, tyypillisesti esityksen lopussa.

Suomessa vierailleet länsiafrikkalaisen tanssin opettajani ovat kaikki olleet tällaisten ammattilaisryhmien jäseniä, mikä on varmasti vaikuttanut siihen, mitä ja miten he opettavat. Ehkä jonkinlaisesta ammattiylpeydestäkin johtuen opettajat mieluummin opettavat pitkiä ja monimutkaisia koreografioita kuin auttavat oppilaitaan ymmärtämään, mitkä ovat kyseisen tanssin tärkeimmät liikkeet ja miten niitä on perinteisten juhlien improvisoiduissa sooloissa tapana yhdistellä. Lisäksi näyttämölle 
sovitetut ryhmäkoreografiat tietenkin sopivat tanssiopetuksen puitteisiin huomattavasti improvisoituja sooloja paremmin. Koska suomalaiset afrikkalaisen tanssin opettajat ovat puolestaan opiskelleet enimmäkseen tällaisten ammattitanssijoiden johdolla, he yleensä seuraavat toisaalta omien opettajiensa esikuvaa ja toisaalta suomalaisen tanssinopetuksen käytäntöjä. Näin ollen tanssinopetus antaa opettajasta riippumatta huomattavan erilaisen kuvan länsiafrikkalaisista tansseista kuin perinteisten juhlien seuraaminen.

Perinteisten esityskäytäntöjen ja muodollisen tanssinopetuksen käytäntöjen välinen etäisyys näkyy myös tanssin ja musiikin suhteessa. Länsiafrikkalaisille perinteille tyypillinen tanssin ja musiikin kiinteä yhteys jää Suomessa usein suhteellisen vähälle huomiolle, sillä tanssitunneilla käydään opiskelemassa vain tanssia ja musiikki tulee tavallisesti levyltä. Levymusiikin käyttö selittää osaltaan sitäkin, miksi tanssiimprovisaatio jää yleensä marginaaliin tanssitunneilla, sillä improvisaation harjoittelu ei ole mielekästä ilman elävää musiikkia. Vaikka tunneilla olisikin säestäjät, ${ }^{3}$ ei koko ryhmän yhteisesti toteuttamassa tanssikoreografiassa voi syntyä vastaavaa vuorovaikutusta tanssijoiden ja muusikoiden välille kuin improvisoiduissa sooloissa. Soolossaan tanssija huomioi rumpuyhtyeen soittaman rytmin, mutta myös rumpalit huomioivat soitossaan tanssijan liikkeet. Useimmiten rumpuyhtyeen solisti seuraa soitollaan tanssijan liikkeitä, ikään kuin soittaen ne kuuluviin tai kommentoiden niitä musiikillisesti. Tällöin tanssija saa välillisesti myös rumpuyhtyeen solistin roolin, sillä rumpusolistin soittamat kuviot perustuvat tanssijan liikkeisiin. Muut rumpalit puolestaan sovittavat omat kuvionsa rumpusolistin mukaan. Tanssitunneilla ryhmän koreografia on kuitenkin etukäteen tiedossa, ja siten rumpalit pystyvät seuraamaan tanssijoiden liikkeitä paremmin kuin improvisoiduissa tanssisooloissa. Mutta koska koreografia on sovittu etukäteen, jäävät improvisaatioille tyypilliset spontaanit reaktiot puuttumaan.

Olen tässä puhunut yleistäen länsiafrikkalaisista tansseista ja välillä jopa afrikkalaisesta tanssista, sillä varsinkin suomalaiset tanssinopettajat opettavat yleensä monia eri maista peräisin olevia tanssityylejä. Esimerkiksi pelkästään tutkimiini senegalilaisiin sabar-tansseihin keskittyviä tanssitunteja ei Suomessa ole tarjolla satunnaisia tiiviskursseja lukuunottamatta. Vaikka opettajat saattavat mainita kulloinkin harjoiteltavan tanssin kulttuurisista yhteyksistä (kuten minkä kansan tanssi on kyseessä ja millaisissa tilanteissa sitä on tapana tanssia), on pääpaino tietenkin itse tanssin opettelussa. Näin tanssien ja rytmien nimet tai muut lisätiedot eivät tunnu painuvan mieleen kovin helposti. Vaikka nimet muistuisivatkin mieleen, eri rytmien ja tanssien erottaminen toisistaan on useimmille harrastajille vaikeaa. Todennäköisesti tietty tanssi ja siihen kuuluva rytmi on helpompi assosioida tilanteeseen, jossa on itse ollut paikalla, kuin jos tanssin olisi oppinut lukuisten muiden tanssien joukossa tanssitunneilla

3 Rumpaleita tulisi länsiafrikkalaisessa tanssimusiikissa yleensä olla vähintään kolme, ja tästä syystä elävän säestyksen käyttäminen tanssitunneilla on usein taloudellisesti mahdotonta. 
Suomessa tapahtuva afrikkalaisen tanssin ja musiikin opiskelu on siis varsin rajallista ennen kaikkea opetustilanteiden luonteesta johtuen, mutta myös siksi, että päteviä opettajia $^{4}$ on täällä vähän, vaikka mukaan laskisi ulkomailla asuvat vierailijatkin. Tanssiopintoni Suomessa ovat tästä kaikesta huolimatta tarjonneet tanssiliikkeiden ja rytmien opettelun ohella muun muassa näkökulmia senegalilaiseen opetuskulttuuriin, ja siten ne ovat tärkeä osa tutkimusprosessiani ja kenttätyötäni. Lisäksi tanssiopintojen yhteydessä syntyneet tuttavuudet ovat laajentaneet kenttääni niin Suomessa kuin muualla. Vaikka joskus voi oppia myös itseltään, kuten edellä olen esittänyt, vaatii tietojen ja taitojen kartuttaminen aina vuorovaikutusta muiden ihmisten kanssa. Siten niin tanssiopinnot kuin kenttätyö ovat luonteeltaan dialogisia prosesseja, ja kentän sosiaalinen verkosto muokkaa väistämättä tutkijan ymmärrystä aiheestaan.

\section{Dialogissa vieraan kulttuurin kanssa}

Kentän ihmissuhdeverkostossa toimiminen edellyttää, että eri osapuolet ymmärtävät toisiaan (Grau 1999: 167-168). Siten kenttätyön ensimmäisiä haasteita on tehdä omat tavoitteensa selväksi niille ihmisille, joilta toivoo saavansa tietoa tutkimuskohteesta. On kyse sitten muusikoista, tanssijoista tai muista ihmisistä, heidän tavoitteensa vaikuttavat vuorovaikutustilanteiden kulkuun siinä missä tutkijankin. Tutkija ei ole koskaan suhteessa vain tietyn kulttuurin edustajiin, vaan hän kohtaa yksilöitä, joilla on erilaisia odotuksia tutkijan suhteen. Esimerkiksi senegalilaiset tanssinopettajani hyötyvät taloudellisesti siitä, että he opettavat minua. Jotkut muusikot ja tanssijat puolestaan toivovat, että tutkimukseni tuo heille mainetta Euroopassa. Vaikka jotkut odotukset ovat epärealistisia, syntyy kentällä myös ystävyyssuhteita, joissa odotukset kohdistuvat ensisijaisesti molemminpuoliseen ymmärrykseen ja yhteydenpitoon.

Kenttätyötä tehdessä on tarpeen arvioida ihmisten motiiveja siinä missä erilaisten olosuhteiden vaikutusta heidän toimintaansa. Vastaavasti kuin kirjallisuutta lukiessa, lähdekritiikkiä on syytä harjoittaa myös suullisten lausuntojen ja ei-sanallisten esitysten tulkitsemisessa: monenlaiset tekijät vaikuttavat siihen, millä tavalla henkilö puhuu tai esiintyy tietyssä seurassa ja tietyssä tilanteessa (esim. Gore 1994: 75). Länsiafrikkalaisissa kulttuureissa vaikuttaa esimerkiksi olevan varsin tavallista, että kysymyksiin ei vastata "en tiedä", vaan vastauksia keksitään mieluummin omasta päästä kuin myönnetään oma tietämättömyys. Tämä ei todennäköisesti ole tarkoituksellista valehtelua, vaan ennemminkin tapa, jolla puhuja pyrkii "säilyttämään kasvonsa" kysyjän silmissä. Mahdollisesti vastaamatta jättämistä pidetään myös epäkohteliaana. Joskus omien tietojen ja taitojen liioittelu on kuitenkin täysin tietoista. Esimerkiksi omaan tuttavapiiriin

4 Pätevyydellä en viittaa tässä muodolliseen tanssinopettajan koulutukseen, vaan tarkoitan joko suomalaisia opettajia, jotka ovat riittävän perehtyneitä jonkin tietyn Afrikan maan tai alueen tansseihin, musiikkiin ja kulttuuriin, tai afrikkalaisia opettajia, jotka ovat sekä hyviä tanssijoita että osaavat opettaa myös suomalaisia oppilaita. 
kuuluvia muusikoita ja tanssijoita usein suorastaan ylistetään Senegalissa, oli kehuihin sitten todellista aihetta tai ei. Siksi tutkijan on parempi luottaa ihmisten toimintaan ja omiin havaintoihinsa enemmän kuin sanallisiin lausuntoihin.

Omat tanssi- ja musiikkiopinnot auttavat arvioimaan esitysten tasoa, samoin kuin monipuoliset katselu- ja kuuntelukokemukset. Kyky itsenäiseen esteettiseen arviointiin ei välttämättä ole ensiarvoisen tärkeää tutkimuksen kannalta, mutta kenttätyössä siitä on ollut paljon hyötyä ainakin minulle. Useat senegalilaiset tuttavani ovat alkaneet suhtautua minuun kunnioittavammin sen jälkeen, kun he ovat huomanneet, että pystyn tekemään tällaisia arvioita. Monien ulkomaalaisten mielestä mikä tahansa senegalilainen tanssi- ja musiikkiesitys on "valtavan upea", joten arviointikyvyllä voi myös osoittaa ymmärtävänsä paikallisia esteettisiä normeja. Senegalilaisten suhtautumiseen vaikuttaa lisäksi se, että olen pitkään jatkuneilla tanssi- ja musiikkiopinnoillani osoittanut olevani aidosti kiinnostunut heidän kulttuuristaan ja että olen käytännön tilanteissa osoittanut esimerkiksi tanssimalla ymmärtäväni sitä. Tärkeiksi ovat osoittautuneet kenttätyössäni nimenomaan pitkäaikaiset kontaktit Senegaliin, sillä molemminpuolinen kunnioitus kehittyy vain ajan kanssa.

Kun kenttätyö on ennen kaikkea yhteydenpitoa vanhoihin tuttuihin, ei heitä näe Toisina tai vieraan kulttuurin edustajina, vaan yksilöinä omine luonteenpiirteineen. Joidenkin ihmisten kanssa ystävystyy kun taas toisten kanssa on vaikea tulla toimeen mahdollisista kulttuurieroista riippumatta. Vastaavasti en senegalilaisten tuttavieni keskuudessa varmasti enää ole vain yksi ulkomaalainen tai suomalainen. Huomio on siis molemmin puolin kiinnittynyt vähitellen yksilöllisiin eroihin kulttuuristen erojen sijaan. Samalla kulttuurisidonnaiset käsitykset ovat alkaneet hahmottua pikemminkin yksilöiden ominaisuuksiksi muiden ominaisuuksien joukossa kuin perustavanlaatuiseksi kulttuuriseksi erilaisuudeksi. Oman ja vieraan kulttuurin vastakkainasettelua ovat purkaneet myös tanssikokemukset: alun perin vieras tanssiperinne on tullut käytännön tanssikokemusten kautta tutuksi, osaksi omaa elämää ja identiteettiä. Omalla kohdallani tilanne on ehkä siitä epätavallinen, että nimenomaan afrikkalainen tanssi on ollut tärkein tanssilajini jo pitkään, ja välillä se on ollut myös ainoa aktiivisesti harrastamani tanssilaji. Siten länsiafrikkalaiset tanssit ovat nykyisin minulle kaikista tutuinta tanssiperinnettä ja samalla tärkeä osa elämääni ja identiteettiäni.

Ajatus kenttätyöstä vuorovaikutustilanteissa tapahtuvana ja omien kokemuksien muotoilemana oppimisprosessina näyttäisi näin ollen tarjoavan mahdollisuuden irrottautua stereotyyppisistä, Toiseutta rakentavista tavoista tarkastella vierasta kulttuuria. Georgiana Gore (1999: 211) tosin huomauttaa, että tutkijan rooliin liittyy väistämättä tutkimuskohteen määritteleminen Toiseksi suhteessa tutkijaan - siinäkin tapauksessa että tutkitaan omaa kulttuuria - sillä muuten aiheen analyyttinen käsittely on mahdotonta. Tällaisen tutkimuksen kannalta välttämättömän etäisyyden ottamisen ei kuitenkaan pitäisi johtaa eksotisoiviin stereotypioihin, tarpeettomaan erilaisuuden rakentamiseen, eikä varsinkaan estää dialogia tutkijan ja tutkimuksen kohteena ole- 
vien Toisten välillä. Jos oletetaan, että vieraita kulttuureja ylipäätään on mahdollista ymmärtää, täytyy lähtökohtana olla ennemminkin samanlaisuus kuin erilaisuus (ks. Agawu 2003: 171). Tutkimuksen yhtenä tavoitteena pitäisi siten olla tutkimuskohteena olevan kulttuurin esittäminen niin, ettei vahvisteta olemassa olevia stereotypioita, vaan tuodaan esille kulttuurin sisäisiä näkökulmia ja niistä syntyviä tulkintoja (esim. Autio 2003: 147-148).

Itseäni eniten häiritsevät stereotypiat, joihin joudun tutkimuksessani väistämättä ottamaan kantaa, liittyvät afrikkalaisen tanssin mystifiointiin ja erotisointiin. Nämä lienevätkin tyypillisimpiä Toiseuden rakentamisen keinoja (ks. esim. Välipakka 2000: 34-35 ja 43-44 intialaisesta tanssista; Laukkanen 2003: 192-195 itämaisesta tanssista). Afrikkalainen tanssi näyttäytyy länsimaisten katsojien silmissä usein hyvin seksuaalisena, ja viihteellisissäkin tanssimuodoissa halutaan jostain syystä nähdä yhteyksiä uskonnollisiin rituaaleihin. Tanssi voi kyllä olla tärkeä osa uskonnollisia rituaaleja Afrikassa, mutta tämä ei tarkoita sitä, että afrikkalainen tanssi olisi aina "hengellistä". Samoin tanssista ruumiillisena ilmaisumuotona voi kaikissa kulttuureissa löytää viittauksia seksuaalisuuteen, eivätkä afrikkalaiset kulttuurit ole poikkeus. On kuitenkin tärkeää tulkita tansseja niiden omista lähtökohdista käsin. Eurooppalaisiin tanssityyleihin tottuneet katsojat yhdistävät esimerkiksi lantion liikkeet automaattisesti seksuaalisuuteen, mutta afrikkalaisissa tansseissa erilaiset keskivartalon liikkeet ovat niin tavallinen piirre, ettei niitä ole syytä tulkita seksuaalisuuden ilmaisuksi elleivät myös muut seikat liikemateriaalissa tai esityskontekstissa viittaa tällaisiin merkityksiin. Ainakin senegalilaisesta näkökulmasta eurooppalaiset paritanssit ovat huomattavasti eroottisempia kuin paikalliset tanssityylit, joissa tanssijoiden välinen fyysinen kosketus on äärimmäisen harvinaista.

Mystifiointia on myös usein toistuva väite afrikkalaisen tanssin "luonnollisuudesta" (esim. Caulker 2003: 19; vrt. Laukkanen 2003: 206-207 itämaisesta tanssista). Tanssi on kuitenkin aina "epätavallista", tyyliteltyä liikettä, vaikka tanssit voivat hyödyntää myös arkista liikemateriaalia (Youngerman 1975: 127, vrt. Lomax et al. 1968: 228). Lisäksi tanssit ovat kaikissa kulttuureissa tavalla tai toisella opittuja. Vaikka tanssin oppimisprosessit eroavat esimerkiksi syntyperäisellä senegalilaisella ja senegalilaisia tansseja opettelevalla suomalaisella, molempien on kuitenkin opittava kyseisten tanssien liikekieli omalla tavallaan samoin kuin tanssityyliin liittyvät ajattelutavat, uskomukset ja merkityksenannot. Muodollisen koulutusjärjestelmän puuttuminen ei siten tee senegalilaisista tansseista luonnollisempia kuin vaikkapa baletista.

Afrikkalaiseen musiikkiin liitettyjä myyttisiä käsityksiä on tarkastellut perusteellisesti Kofi Agawu (2003), jonka huomiot sivuavat ajoittain myös tanssia. Monet hänen käsittelemistään myyteistä ovat saaneet alkunsa siitä, että tutkijat eivät ole itse osanneet soittaa tai tanssia tutkimiaan tyylejä. Tuskin kenellekään, joka on tutustunut länsiafrikkalaiseen musiikkiin ja tanssiin käytännössä, tulisi mieleen merkitä eri rumpujen rytmit eri tahtilajeihin, saati väittää, että tanssijan kehon eri osat liikkuisivat 
eri tahtilajeissa ${ }^{5}$ (ks. Agawu 2003: 66-67 ym.). Tanssimisen kokemusten perusteella on selvää, että tanssija hahmottaa liikkeet yhtenä kokonaisuutena eikä useina samanaikaisina kuvioina, sillä jos eri ruumiinosien liikkeitä joutuu miettimään erikseen, ei tanssi tunnu eikä näytä luontevalta. Kun kyseiset tutkijat eivät edes tarjoa esimerkkejä siitä, miten tällainen polymetriikka toteutuu tanssissa, voi hyvällä syyllä arvella, että kyseessä on yksi myyteistä, joiden avulla afrikkalainen musiikki ja tanssi on konstruoitu perustavanlaatuisesti erilaiseksi kuin länsimainen.

Tutkijat saattavat pitää yllä tällaisia myyttejä uskoen, että juuri erilaisuus tekee heidän tutkimuskohteestaan tutkimisen arvoisen. Myyttejä varmasti tukee monien afrikkalaisen tanssin ja musiikin harrastajien halu löytää harrastuksestaan jotain eksoottista, jonka avulla he voivat irtautua omasta arkielämästään. Eksotiikka on muutenkin hyvä "myyntivaltti", joten myös afrikkalaiset itse ylläpitävät tällaisia myyttejä - muistan Senegalissa kuulleeni muun muassa väitteen: "meillä afrikkalaisilla on rytmi veressä". Vieraan kulttuurin tutkimuksessa vertailu tutkijan omaan kulttuuriin on todennäköisesti välttämätöntä, mutta erilaisuuden korostaminen on eettisesti kyseenalaista. Agawun (2003: 156) mukaan ilmiöiden esittäminen "erilaisina" merkitsee samalla niiden haltuunottoa, eli kyseessä on yksi tapa painottaa tutkijan valta-asemaa suhteessa tutkimuskohteeseensa. Tämä onkin yksi syy, miksi haluan hahmottaa kentän ja kenttätyön tavalla, joka korostaa dialogia eikä erottele kentän muodostavia ihmisiä "meihin" ja "muihin".

Lisäksi on syytä muistaa, että kentän näkökulmasta tutkija on monissa tilanteissa itse se, joka edustaa vierasta kulttuuria. Näin ollen tutkija ei ole ainoa, joka joutuu totuttelemaan itselleen vieraisiin ajattelu- ja toimintatapoihin. Hänelle se on kuitenkin tutkimuksen kannalta välttämättömyys, kun taas muut voivat yhtä hyvin kieltäytyä yhteistyöstä tutkijan kanssa. Siten tutkija on kenttänsä armoilla, riippuvainen kontaktihenkilöidensä halukkuudesta vuorovaikutukseen tutkijan kanssa. Näiden ihmisten odotukset vuorovaikutuksen suhteen eivät tietenkään lopu siihen, kun tutkija saa tutkimuksensa valmiiksi. Siksi on loukkaavaa, jos tutkija ei enää tutkimuksensa päätyttyä ole lainkaan kiinnostunut niistä ihmisistä, joiden kanssa käytyjen - sanallisten ja ei-sanallisten - dialogien varaan hänen tutkimuksensa on rakentunut. Tästä johtuen ei välttämättä ole huono asia, jos tutkimuksen avainhenkilöt ovat myös ystäviä, vaikka tästä seuraakin, että kenttätyötä on vaikea tai jopa mahdoton pitää erillään tutkijan muusta elämästä (Kisliuk 1997: 24; Grau 1999: 167). Päinvastoin kentällä käydyt dialogit ja yhteisesti jaetut kokemukset kiinnittävät tutkijan pysyvästi kentän ihmissuhdeverkostoon.

5 Pisimmälle tämän ajatuksen on vienyt Helmut Günther (1970: 61-63 ym.), ja sama ajatus toistuu uusimmissakin lähteissä, esim. Welsh Asante (1998: 216-219). 


\section{Lopuksi: tietämisestä ja ymmärtämisestä}

Koska tanssia kulttuurisena ilmaisumuotona ei ole mahdollista mitata tai selittää pelkkiä tosiseikkoja hyödyntäen (Kaeppler 1999: 22), on ehkä syytä pohtia, mitä tanssista voi tietää. Varsinkin kenttätyössä tietämistä ja ymmärtämistä on vaikea erottaa toisistaan. Esimerkiksi haastattelujen kautta voin tietää, mitä tanssijat itse sanovat tanssinsa tarkoittavan, mutta jos en ymmärrä heidän tapaansa ilmaista asioita, en pysty arvioimaan sitä, mitä he sanoillaan oikeastaan tarkoittavat. Mitä paremmin taas ymmärrän vieraan kulttuurin ajattelu- ja toimintatapoja, sitä vaikeampi on perustella, miten tiedän heidän tarkoittavan juuri tiettyä asiaa enkä jotain muuta. Tutkijan kokemien vuorovaikutustilanteiden muovaamaa kulttuurista ymmärrystä voi siten olla mahdotonta sanallistaa, mutta samalla se näyttää tarjoavan tavan irrottautua stereotyyppisistä tavoista tarkastella vierasta kulttuuria. Jos tutkija on oppimisprosessissaan onnistunut käymään tasavertaisia dialogeja kentällään ja niiden avulla tavoittamaan edes jossain määrin tutkimalleen kulttuurille ominaiset ajattelu- ja toimintatavat, on hän varmasti joutunut kyseenalaistamaan kyseistä kulttuuria koskevat stereotypiat. Erityisesti oman ruumiin kautta tutuksi, jopa arkipäiväiseksi, tullutta tanssiperinnettä on vaikea nähdä eksoottisena Toisena.

Kuten tässä artikkelissa olen kuvannut, kentän ihmissuhdeverkostoissa dialogia käydään monissa muissakin muodoissa kuin sanallisesti, eikä näissä monenlaisissa dialogeissa saatuja tietoja ole aina helppoa tai edes mahdollista dokumentoida. Loppujen lopuksi vain harvoin kulttuurista tietoa saadaan muodossa, joka on helppo kirjata muistiin, niin että siihen pystyy myöhemmin kätevästi viittaamaan. Ymmärrys tutkimusaiheesta päinvastoin karttuu vähitellen, ja joidenkin tilanteiden merkitys saattaa valjeta vasta vuosia myöhemmin. Siksi tutkijan täytyy tietoisesti tarkastella omaa oppimisprosessiaan eli tietyllä tapaa etäännyttää itsensä paitsi tutkimuskohteestaan myös omista kokemuksistaan (mm. Herndon 1993: 68). On kuitenkin vaikea arvioida, kuinka paljon tutkijan on kerrottava itsestään, omasta taustastaan ja tutkimusprosessin kulusta, jotta lukija pystyy arvioimaan etnografisen tiedon paikkansa pitävyyttä. Refleksiivinen kirjoitustyyli saattaa olla jopa eettisesti kyseenalainen, jos tutkijan kokemukset nousevat etnografisen kuvauksen keskiöön varsinaisen tutkimuskohteen sijaan (Agawu 2003: 214-218; Grau 1999: 164). Vaikka tutkijan ymmärrys aiheestaan muotoutuukin kentällä käytyjen dialogien pohjalta, etnografia ei voi olla pelkästään tutkijan kenttätyön representaatiota (vrt. Kisliuk 1997: 41). Sen sijaan etnografian pitäisi olla dokumentti tutkimuksen kohteena olevasta kulttuurista sellaisena kuin tutkija on sen kentällään ymmärtänyt. 


\section{Lähteet}

Agawu, Kofi (2003) Representing African Music. Postcolonial Notes, Queries, Positions. New York \& London: Routledge.

Autio, Petra M. (2003) "Nostan tanssini kovaan lyöntiin. Kiribatilainen tanssi, sosiaalisuus ja kovuuden käsite". Tanssi tanssi. Kulttuureja, tulkintoja. Toim. Helena Saarikoski. Tietolipas 186. Helsinki: Suomalaisen Kirjallisuuden Seura. Ss. 147-188.

Caulker, Ferne Yangyeitie (2003) "African Dance: Divine Motion". The Dance Experience. Insights into History, Culture and Creativity. Toim. Myron Howard Nadel \& Marc Raymond Strauss. Hightstown, NJ: Princeton Book Company. Ss. 17-28.

Foster, Susan Leigh (1997) "Dancing Bodies". Meaning in Motion. New Cultural Studies of Dance. Toim. Jane C. Desmond. Durham \& London: Duke University Press. Ss. 235-257.

Gore, Georgiana (1994) "Traditional dance in West Africa". Dance History. An Introduction. Second Edition. Toim. Janet Adshead-Lansdale \& June Layson. London \& New York: Routledge. Ss. 59-80.

Gore, Georgiana (1999) "Textual Fields: Representation in Dance Ethnography". Dance in the Field. Theory, Methods and Issues in Dance Ethnography. Toim. Theresa J. Buckland. Houndmills \& London: Macmillan Press. Ss. $208-220$

Grau, Andrée (1999) "Fieldwork, Politics and Power". Dance in the Field. Theory, Methods and Issues in Dance Ethnography. Toim. Theresa J. Buckland. Houndmills \& London: Macmillan Press. Ss. 163-174.

Günther, Helmut [1969] (1970). Grundphänomene und Grundbegriffe des afrikanischen und afro-amerikanischen Tanzes. Beiträge zur Jazzforschung (Studies in Jazz Resesarch) 1. Wien: Universal Edition.

Hastrup, Kirsten (1995) A passage to anthropology. Between experience and theory. London \& New York: Routledge.

Herndon, Marcia (1993) "Insiders, Outsiders: Knowing Our Limits, Limiting Our Knowing". The World of Music 35 (1). Ss. $63-80$.

Hoppu, Petri (2003) "Tanssintutkimus tienhaarassa”. Tanssi tanssi. Kulttuureja, tulkintoja. Toim. Helena Saarikoski. Tietolipas 186. Helsinki: Suomalaisen Kirjallisuuden Seura. Ss. 19-51.

Kaeppler, Adrienne L. (1999) "The Mystique fo Fieldwork" Dance in the Field. Theory, Methods and Issues in Dance Ethnography. Toim. Theresa J. Buckland. Houndmills \& London: Macmillan Press. Ss. 13-25.

Kisliuk, Michelle (1997) "'(Un)doing Fieldwork: Sharing Songs, Sharing Lives". Shadows in the Field. New Perspectives for Fieldwork in Ethnomusicology. Toim. Gregory F. Barz \& Timothy J. Cooley. New York \& Oxford: Oxford University Press. Ss. 23-44.

Kubik, Gerhard (2000) "Interconnectedness in Ethnomusicological Research". Ethnomusicology 44 (1). Ss. 1-14.

Laukkanen, Anu (2003) "Luonnollista liikettä, epäsopivia asentoja. Haastattelututkimus itämaisen tanssin liikekielestä Suomessa". Tanssi tanssi. Kulttuureja, tulkintoja. Toim. Helena Saarikoski. Tietolipas 186. Helsinki: Suomalaisen Kirjallisuuden Seura. Ss. 191-223.

Lomax, Alan \& Bartenieff, Irmgard \& Paulay, Forrestine (1968) "Dance Style and Culture". Alan Lomax: Folk Song Style and Culture. Washington, DC: American Association for the Advancement of Science. Ss. 222-247.

Myers, Helen (1992) "Fieldwork". Ethnomusicology. An Introduction. Toim. Helen Myers. London \& Houndmills: Macmillan Press. Ss. 21-49.

Seeger, Anthony (1992) "Ethnography of Music". Ethnomusicology. An Introduction. Toim. Helen Myers. London \& Houndmills: Macmillan Press. Ss. 88-109.

Välipakka, Inka (2000) "Monikulttuurinen intialainen tanssi: Naisten dialogi haastaa eksoottisuuden". Musiikin suunta 4/2000. Ss. 30-46.

Welsh Asante, Kariamu [1994] (1998). "The Zimbabwean Dance Aesthetic: Senses, Canons, and Characteristics". African Dance: an Artistic, Historical and Philosophical Inquiry. Toinen painos. Toim. Kariamu Welsh Asante. Trenton: Africa World Press. Ss. 203-220.

Youngerman, Suzanne (1975) "Method and Theory in Dance Research: An Anthropological Approach". Yearbook of the International Folk Music Council, vol. 7. Ss. 116-133. 